https://doi.org/10.5817/OS2020-4-6

\title{
Proběhla konference Studentské dialogy o východní Evropě II (Brno-Olomouc-Praha)
}

Dne 14. ř́jina 2020 proběhla doktorandská meziuniverzitní mezioborová konference, která byla - tak jako téměř všechny události této „koronavirové doby“ - pouze online v podobě videokonference. Setkání bylo již druhým v pořadí a neslo název Studentské dialogy o východní Evropě II (Brno-Olomouc-Praha). První ročník konferenční řady proběhl loni na FF UK v Praze a jde o jeden $\mathrm{z}$ výsledků spolupráce všech tří zúčastněných pracovišt v rámci programu MŠMT Podpora strategicky významných programů na Filozofických fakultách UK, MU, UP.

Na úvod naší zprávy je třeba zmínit, že online podoba se na samotné konferenci podepsala minimálně a dá se říct, že pouze technicistně: účast byla vysoká (14 vystupujících) a nemálo bylo i těch, kteří sice nevystupovali se svým příspěvkem, ale zapojili se do diskusí.

Průběh konference zajištoval Ústav slavistiky FF MU, a to pod záštitou děkana FF MU prof. Milana Pola. Po úvodních slovech hlavního organizátora celé akce doc. PhDr. Jiř́ho Gazdy, CSc., promluvil proděkan pro vědu a výzkum FF MU prof. PhDr. Petr Kyloušek, CSc., vedoucí Ústavu slavistiky FF MU prof. PhDr. Ivo Pospíšil, DrSc., děkan FF UP prof. PhDr. Zdeněk Pechal, CSc., a ředitel Ústavu východoevropských studií FF UK PhDr. Stanislav Tumis, M.A., Ph.D., načež následovala první ze tří sekcí, jazykovědná, počtem prríspěvků největší.

Všech šest př́ispěvků $v$ jazykovědné sekci mělo rusko(ukrajinsko)-český komparativní charakter. První vystupující byla Mgr. Oksana Dunajeva (UP) s referátem Rusko-česká terminologie internetového marketingu, v němž srovnala př̀edevším možnosti adaptace cizích (zejména anglických) termínů do ruštiny a češtiny. Mgr. Viktoriya Machek (UP) se v př́spěvku Фемінізація та фемінативи у західноукраїнських друкованих виданнях 20-3о років $\mathrm{XX}$ столітmя věnovala tzv. feminativům, tj. pojmenováním ženského rodu vzniklým přechýlením $\mathrm{z}$ mužské formy $\mathrm{v}$ západní ukrajinštině 20.-30. let 20. století. Mgr. Galina Prokudina (MU) účastníkům přibližila téma své disertace v prŕspěvku Концепт война в русских паремиях (и сравнение с концептом «война» в поэме А. Т. Твардовского «Василий Тёркин»). Dochází zde mj. k závěru, že na rozdíl od ruštiny má čeština velmi málo př́isloví a pořekadel spojených s válkou. Čtvrtou vystupující byla Mgr. Ekaterina Rycheva, Ph.D. (UK) s referátem Имиджевые жанры политического дискурса в России и Чехии (на материале публичных выступлений политиков), v němž se věnovala navýsost aktuálnímu tématu diskursu politických vystoupení, manipulaci apod. V příspěvku 
Ruský výraz это a jeho české prekladové ekvivalenty se Mgr. Viktor Vymazal (UP) zabýval ruským výrazem эmo a jeho ekvivalenty v češtině. Konstatuje mj., že nejčastější překlad jako to nemusí být vždy nejvhodnější. Šestou vystupující, která uzavřela jazykovědnou sekci, byla Mgr. Magdaléna Žaloudíková (UP). Ve svém vystoupení nazvaném Prostředky jazykové ekonomie z pohledu typologie jazyka (na materiále ruského, českého a anglického jazyka) ukázala na možnosti jazykové ekonomie, které jsou v uvedených jazycích různé, nicméně v jednotlivých oblastech se k sobě jazyky přibližují či oddalují nehledě na svou typologii.

Druhou sekcí byla sekce literárněvědná. Mgr. Krystyna Kuznietsova (MU) $\mathrm{v}$ př́spěvku Město jako domov a jeho vliv na formování národní identity v současné ukrajinské literatuře zkoumala diskurs města v současné ukrajinské literatuře, jenž je spojen s hledáním vlastního já a vlastní identity. PaedDr. Lenka Odehnalová (MU) se dlouhodobě věnuje F. M. Dostojevskému a nejinak tomu bylo i v jejím příspěvku Recepce Dostojevského Deníku spisovatele v českém a slovenském prostředí, v němž se, jak už název napovídá, věnovala recepci Deníku spisovatele v českém a slovenském prostředí a jeho př̀kladům. Mgr. Hanna Paulouskaya (MU) se podobně jako G. Prokudina věnovala tématu války - Изображение войны в творчестве Виктора Астафьева (на материале романа «Прокляты и убиты»). Autorka se věnuje odkrývání Astafjevova postoje $\mathrm{k}$ tématu války a mj. také pojednává o vzniku a vývoji válečné prózy. Zamjatinovým románem $M y$ se zabýval Mgr. Fjodor Vinokurov (MU) v referátu Чешское издание романа Е. Замятина «МЫ» (1927) как объект межкультурной коммуникации. V něm přiblížil specifika recepce překladového díla, problematiku jejich recenzí v tisku atd. Mgr. René Andrejs (UP) v př́spěvku Надежда Филаретовна Мельникова-Папоушкова на странища эмигрантских журналов pojednal o ruských emigrantských časopisech vydávaných ve 2o. letech v Československu. Jeho příspěvek byl zároveň posledním v literárněvědné sekci.

Konferenci uzavírala kulturně-historická část. Tu zahájila Mgr. Olga Leshkova (UK); věnovala se období tzv. smuty v př́spěvku Mytologizace Období zmatkư $v$ ruské literatuře a umění v kontextu historické paměti. Šlo jí především o zkoumání mytologizace událostí a účastníků tohoto období. O poněkud mladší historické události přednášel Mgr. Radomyr Mokryk (UK) v příspěvku Hybridní ukrajinizace: národnostní otázka $v$ sovětské Ukrajině v době Chruščovová Tání. V něm pojednal o Chruščovově tajném projevu, následném období tání, národností a jazykové politice tehdejší doby a jiných aspektech této éry. Sekci a zároveň konferenci uzavřel filozofický př́spěvek Mgr. Jakuba Múčky (UK) Filosofie naděje N. A. Berd’ajeva. Autor zkoumal, nakolik může být Bedajevovo myšlení aktuální i pro současné debaty o křestanské filozofii naděje, a to především uvnitř ruské pravoslavné společnosti.

Všechny př̀ednesené prŕíspěvky vycházely bud’ z obhájených magisterských diplomových prací, nebo z rozpracovaných disertačních prací a ke všem referátům 
bylo v jednotlivých diskusích položeno množství zajímavých dotazů a zaznělo mnoho neméně zajímavých odpovědí a podnětných postřehů.

O hladký průběh konference se postupně starali čtyři doktorandi Ústavu slavistiky FF MU: Mgr. Zbyněk Michálek, Mgr. Světlana Michálková, Iuliia Dmitrieva a Mgr. Lenka Heinigová; konferenci je tak skutečně možné označit za vpravdě doktorandskou.

Je potěšující, že i v omezených podmínkách, které jsou způsobeny současnou epidemiologickou situací, v podmínkách, kdy bohužel není možné se fyzicky setkávat, se podařilo zorganizovat setkání zcela plnohodnotně. Doufejme, že další ročník proběhne již klasickou formou, bez omezení, i když by jistě stálo za zvážení, zda nějakou formu dálkových videopříspěvků i tak nevyužít; možná, že je to pro někoho pohodlnější a technické vybavení je dnes (nejen po koronavirových zkušenostech z jara) na takové úrovni, že takové zapojení beze všeho umožňuje.

Zbyněk Michálek

Toto dílo lze užít v souladu s licenčními podmínkami Creative Commons BY-SA 4.0 International (<https:// creativecommons.org/licenses/by-sa/4.0/legalcode>). Uvedené se nevztahuje na díla či prvky (např. obrazovou či fotografickou dokumentaci), které jsou v díle užity na základě smluvní licence nebo výjimky či omezení príslušných práv. 
